\title{
PENGARUH PERBEDAAN LAJU WAKTU PROSES PEMBEKUAN HASIL COR ALUMINIUM 319 DENGAN CETAKAN LOGAM TERHADAP STRUKTUR MIKRO DAN SIFAT MEKANIS
}

\author{
Errens Lowther ${ }^{1)}$, Sofyan Djamil ${ }^{1)}$ dan Eddy S. Siradj ${ }^{2)}$ \\ 1) Program Studi Teknik Mesin Fakultas Teknik Universitas Tarumanagara, Jakarta \\ 2) Departemen Material dan Metalurgi Fakultas Teknik Universitas Indonesia, Jakarta \\ e-mail : errens.lowther@rocketmail.com
}

\begin{abstract}
Aluminum alloy is a raw material in industry. Aluminum alloy used is aluminum alloy aluminum alloy 319. Materials were investigated to obtain aluminum alloys that have strong mechanical properties of the difference in the rate of clotting. Research 319 aluminum alloy was investigated by conducting the smelting process in the crank case and printed materials by using metal molds, then do differences in rates of freezing process with an open-air media, media dry sand and wet sand media as a medium deceleration. The next step is testing using tensile testing, testing, hardness with Brinell method, and metallography. From the results, with the help of wet sand media has a hardness of 68 BHN and the UTS 241.89 MPa, for open air medium hardness of $62 \mathrm{BHN}$ and the UTS 224.03 MPa and dry sand media assistance hardness of $54 \mathrm{BHN}$ and the UTS $190.9 \mathrm{MPa}$.
\end{abstract}

Keywords : Aluminum, casting, metal mold, mechanical properties and microstructure.

Abstrak : Alumunium alloy merupakan bahan baku dalam dunia perindustrian. Alumunium alloy yang digunakan adalah alumunium alloy 319. Bahan alumunium alloy ini diteliti untuk mendapatkan alumunium alloys yang mempunyai sifat mekanis yang kuat dari perbedaan laju pembekuan. Penelitian alumunium alloy 319 ini diteliti dengan melakukan proses peleburan pada bahan crank case dan dicetak dengan menggunakan cetakan logam, kemudian dilakukan perbedaan laju proses pembekuan dengan media udara terbuka, media pasir kering, dan media pasir basah sebagai media perlambatannya. Proses selanjutnya adalah pengujian dengan menggunakan pengujian tarik, pengujian, kekerasan dengan metode Brinell, dan metalografi. Dari hasil penelitian didapatkan dengan menggunakan bantuan media pasir basah memiliki nilai kekerasan sebesar 68 BHN dan nilai UTS 241,89 MPa, untuk media udara terbuka nilai kekerasan sebesar 62 BHN dan nilai UTS 224,03 MPa dan bantuan media pasir kering nilai kekerasan sebesar 54 BHN dan nilai UTS 190,9 MPa.

Kata Kunci : Alumunium peleburan, cetakan logam, sifat mekanis dan struktur mikro.

\section{PENDAHULUAN}

Pengecoran Logam merupakan salah satu ilmu keteknikan yang perkembangannya cukup pesat saat ini. Untuk itu, perlu didukung dengan pengembangan fasilitas pengecoran logam yang selanjutnya dapat dicetak ke dalam berbagai jenis mold yang ukurannya sesuai dengan standard uji mekanis di laboratorium metalurgi agar mahasiswa teknik mesin Universitas Tarumanagara mampu memahami pengetahuan tentang langkah-langkah proses pengecoran dan struktur material logam khususnya aluminium setelah lulus nanti.

Dalam pertimbangan hal tersebut maka direncanakan pembuatan sebuah crucible dengan kapasitas $3 \mathrm{~kg}$ untuk kebutuhan laboratorium metalurgi, dengan menggunakan crucible berbahan graphite dan menggunakan bahan bakar gas LPG sebagai pemanasnya. Langkah selanjutnya dilakukan proses peleburan pada bahan cor, yang kemudian akan dicetak dengan menggunakan cetakan logam, dan dilakukan perbedaan laju waktu proses pembekuan dengan menggunakan 3 variabel yaitu dengan udara terbuka, dengan bantuan media pasir kering, dan bantuan media pasir yang dibasahi dengan air.

\section{METODE PENELITIAN}

Dalam melakukan pengolahan data pada hasil penelitian ini, peneliti mengumpulkan data hasil eksperimen dengan menggunakan tabel dan gambar pada masing-masing variabel yang sudah di uji. Tujuan dari penggunaan tabel dan gambar adalah untuk memudahkan pembaca agar dapat melihat perbedaan antar tiap variabel. Penentuan variabel ini juga tidak dilakukan penulis seorang 
diri, melainkan dengan hasil diskusi dengan dosen pembimbing. Dalam melakukan analisa struktur mikro dan pengujian kekerasan, peneliti melakukan pengambilan data dalam 3 titik yang berbeda dan kemudian dirata-ratakan. Sedangkan untuk pengujian tarik, penulis melakukan pengujian sebanyak 3 specimen pada tiap variabel dan diambil rata-ratanya. Langkah-langkah proses penelitian yang dilakukan, yaitu:

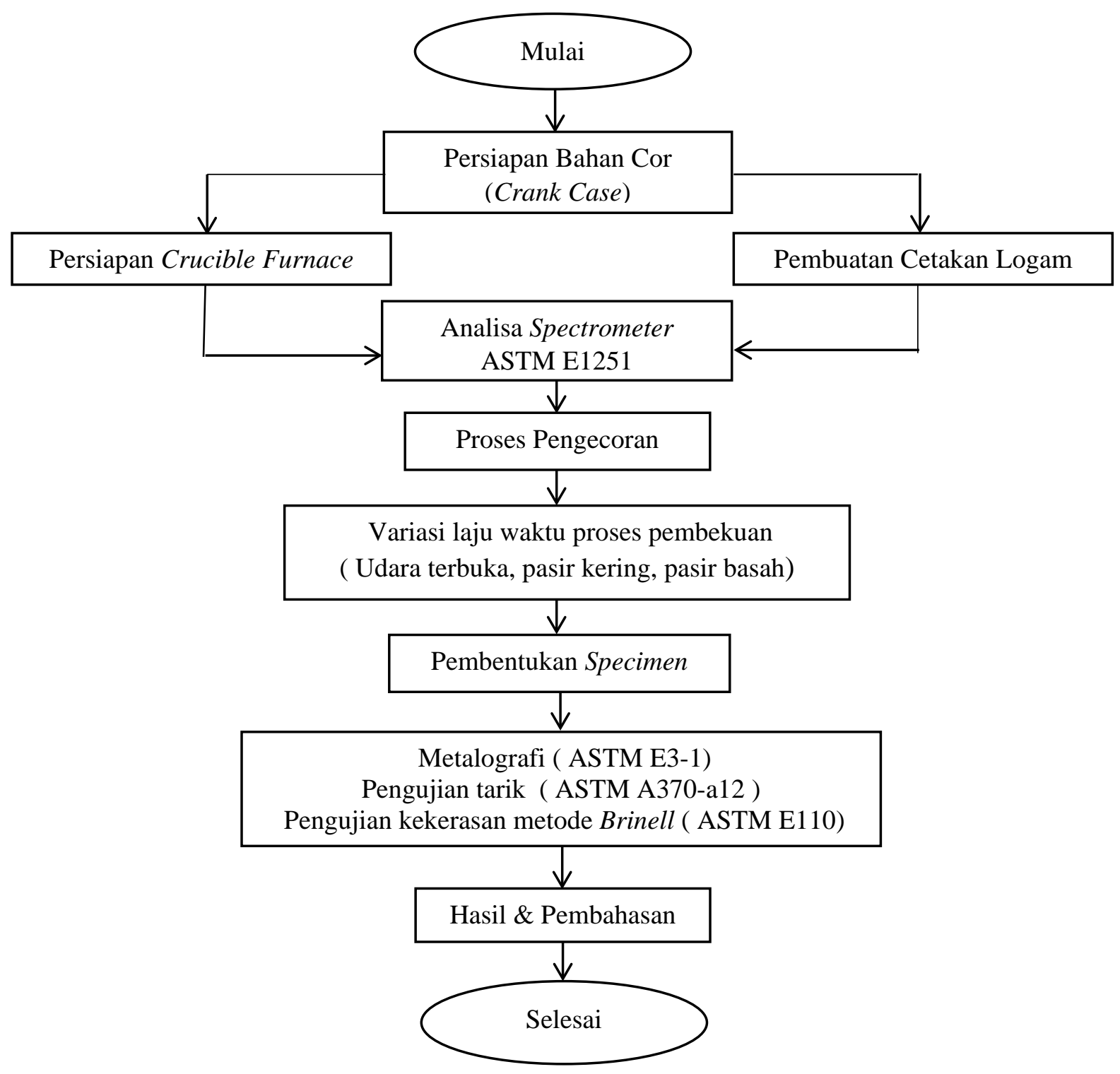

Gambar 1. Diagram Alir Penelitian

\section{Persiapan bahan cor}

Prosedur penelitian memiliki beberapa tahapan yaitu:

Crank case yang digunakan adalah crank case bekas, sehingga dalam persiapannya perlu dibersihkan dengan menggunakan besin agar oli yang menempel pada crank case hilang dan terakhir menggunakan sabun untuk menghilangkan sisa bensin. Material dari crank case merupakan aluminium paduan.

\section{Persiapan crucible furnance}

Dalam proses pengecoran crank case, dibutukan crucible furnance yang memiliki kemampuan lebur dengan suhu yang cukup tinggi. Karena itu, bahan yang digunakan sebagai dinding penahan panas adalah castable tipe c-14 dengan nilai titik lebur mencapai $1400^{\circ} \mathrm{C}$. Selain 
itu bahan dari media yang digunakan sebagai wadah lebur (crucible) adalah graphite dengan nilai titik leburnya $1200^{\circ} \mathrm{C}$, lalu sebagai pemanas digunakan burner dan regulator high preassure berbahan bakar LPG. Ilustrasi dari dari dimensi crucible furnance dapat dilihat pada gambar 2.
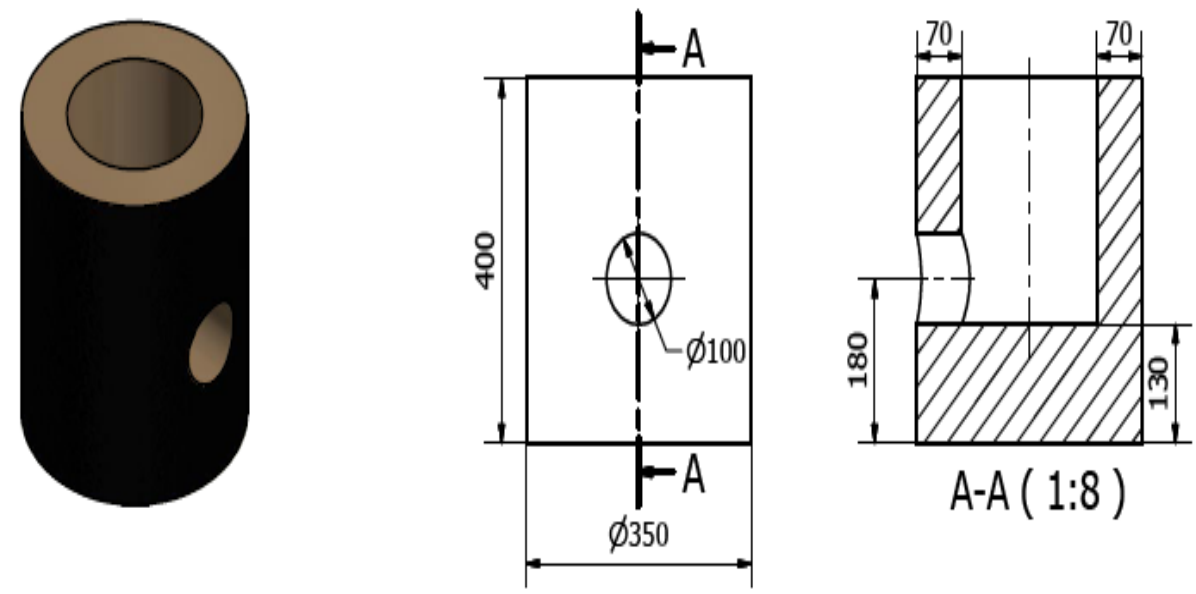

Gambar 2. Ilustrasi Dimensi Dari Crucible Furnance (skala 1 : 70)

\section{Pembuatan cetakan logam}

Pada Gambar 3 merupakan dimensi dari pola cetakan logam yang dihasilkan dengan mengunakan mesin milling CNC yang terdapat di lab CNC, Universitas Tarumanagara. Cetakan logam ini dibuat dengan menggunakan bahan baja 1018 (ST 41). Pemilihan bahan cetakan logam ini didasarkan dari nilai titik lembur baja 1018 (ST 41) yang lebih tinggi dibandingkan dengan titik lebur aluminium yaitu $1500^{\circ} \mathrm{C}$ sehingga cetakan ini dapat digunakan sebagai pola untuk hasil proses pengecoran bahan baku crank case yang berbahan dasar aluminium. Selain itu hasil coran crank case tidak akan lengket dengan baja 1018 (ST 41) dan tidak ada kontaminasi / pelepasan kandungan-kandungan kimia dari baja 1018 (ST 41) kedalam hasil coran crank case.

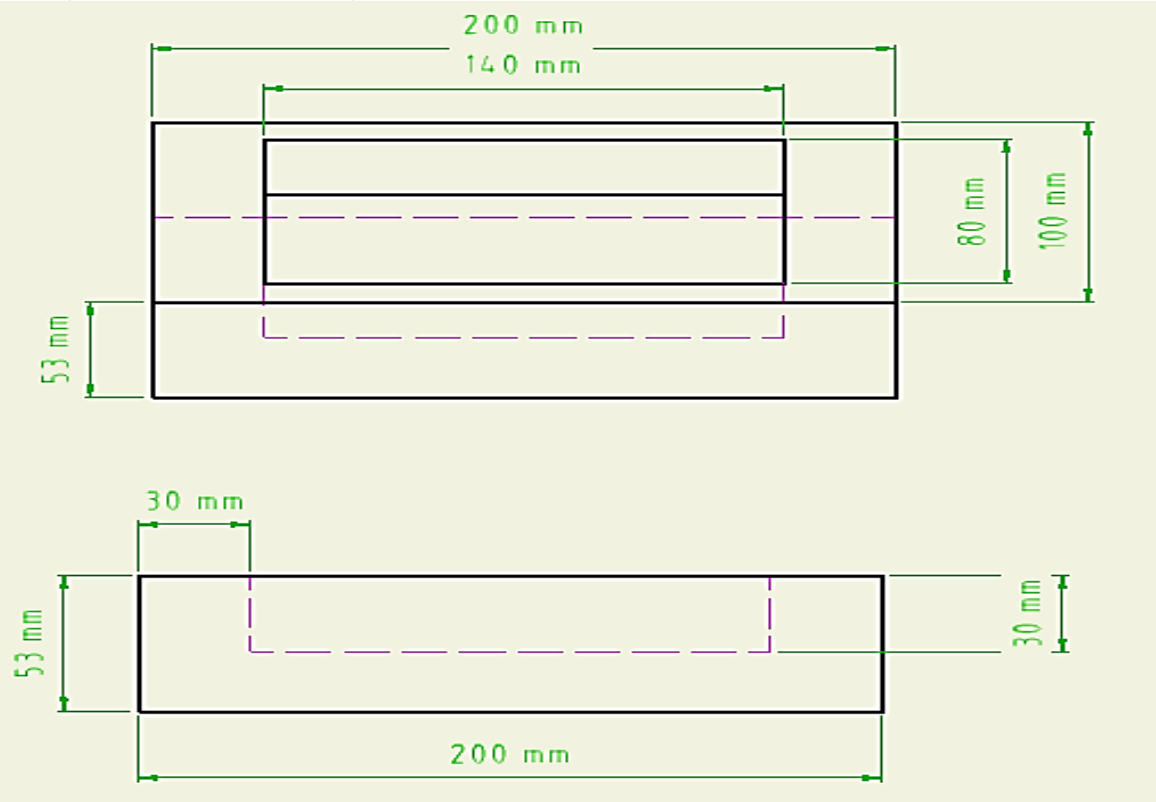

Gambar 3. Ilustrasi Cetakan Logam (skala $1: 3$ )

\section{Analisis spectrometer}

Analisis spectrometer dilakukan untuk mengetahui komposisi kimia dari crank case yang digunakan sebagai bahan baku cor dan sebagai penentu kategori / jenis aluminium dari crank case. Selain itu, hasil dari analisis spectrometer juga akan digunakan sebagai referensi untuk mengetahui perubahan fasa pada saat proses pengecoran dan untuk menentukan titik lebur dari bahan baku cor. 
Proses analisa spectrometer pada penelitian ini dilakukan di lab uji Departemen Teknik Metalurgi \& Material, Universitas Indonesia.

\section{Proses pengecoran}

Pada proses pengecoran, terdapat beberapa hal yang harus dipersiapkan terlebih dahulu yaitu bahan baku cor, crucible, thermocouple, cetakan logam dan komponen pendukung lainnya. Setelah persiapan selesai, langkah berikutnya adalah proses pengecoran. Berikut adalah langkah-langkah dalam proses pengecoran:

a. Meletakan bahan baku cor yang sudah dipotong menjadi ukuran yang lebih kecil kedalam crucible.

b. Mulai nyalakan burner yang sudah dipersiapkan sebelumnya, dan letakan thermocouple kedalam crucible agar peningkatan suhu yang terjadi didalam crucible furnance dapat kita ketahui.

c. Menunggu hingga suhu didalam crucible furnance mencapai suhu $\pm 720^{\circ} \mathrm{C}$ agar bahan baku crank case mencair secara menyeluruh.

d. Memasukan flux kedalam bahan baku yang sudah mencair, kemudian mengaduk hingga flux larut secara merata lalu diamkan selaju 5-10 menit. Flux berfungsi sebagai zat kimia pengikat kotoran, sehingga kotoran yang terdapat dalam bahan baku cor menggumpal dan dapat dibuang dengan mudah.

e. Setelah cairan bahan baku cor bersih, proses penuangan dilakukan kedalam cetakan logam dengan memvariasikan laju waktu proses pembekuan, yaitu dengan bantuan media udara terbuka, pasir kering, dan pasir yang dibasahkan dengan air.

f. Melakukan pendataan penurunan temperatur dari variasi laju waktu proses pembekuan hingga mencapai suhu ruangan terbuka $\left(30^{\circ} \mathrm{C}\right)$ pada cetakan logam. Setelah mencapai suhu ruangan terbuka, lepaskan hasil cor dari cetakan logam untuk dilakukan proses pembentukan specimen.

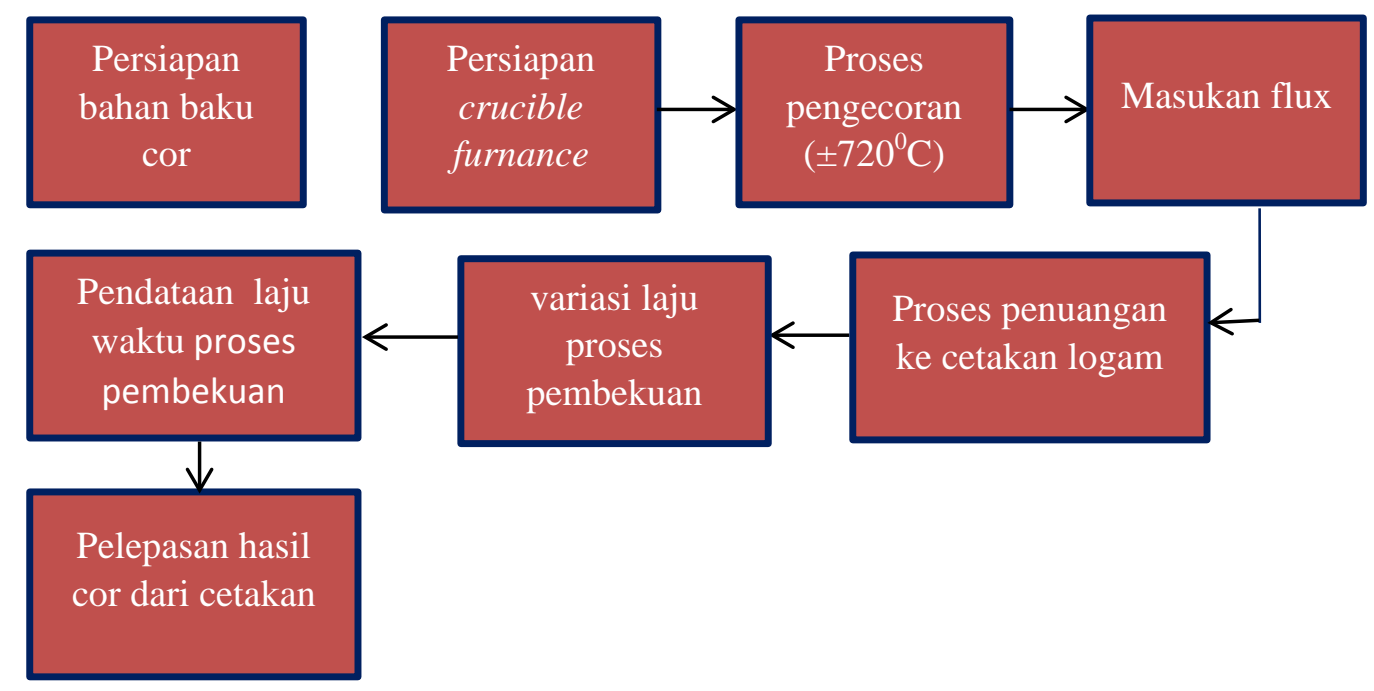

Gambar 4. Tahapan Proses Pengecoran Dengan Bahan Baku Crank Case

\section{Variasi Laju Waktu Proses Pembekuan}

Pada penelitian ini membahas tentang pengaruh laju pembekuan terhadap struktur mikro dan sifat mekanis hasil cor dengan cetakan logam. Oleh karena itu, diperlukan bantuan media untuk mempengaruhi laju penurunan temperatur pada saat proses pembekuan selain dengan proses pengecoran dengan udara terbuka. Media bantuan yang digunakan pada penelitian ini adalah pasir kering dan pasir yang sudah dibasahi dengan air. Pada gambar 5 merupakan ilustrasi dari penggunaan pasir kering dan pasir basah pada saat proses pembekuan dengan cetakan logam dengan cara dipendam. 

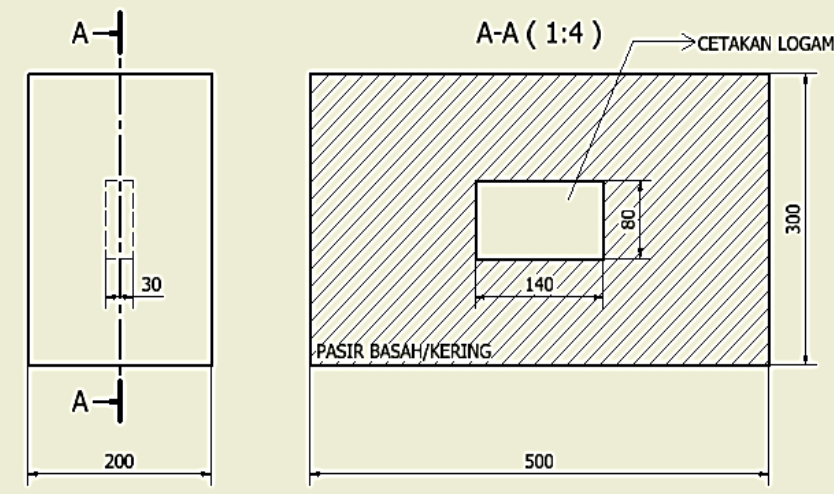

Gambar 5. Ilustrai penggunaan media pasir kering dan pasir basah (skala $1: 20$ )

\section{Pembentukan Specimen}

Dalam proses pembentukan specimen, digunakan mesin CNC milling yang berada di lab CNC, Universitas Tarumanagara. Pada penelitian ini digunakan standard ASTM E3-1 untuk metalografi, standard ASTM E 110 untuk pengujian kekerasan metode Brinell, dan standard ASTM A a370-12a untuk pengujian tarik. Setalah pembentukan specimen selesai, langkah selanjutnya adalah proses penghalusan specimen menggunakan amplas $(500,1000)$ dan proses pemolesan dengan menggunakan autosol untuk specimen Brinell dan specimen uji tarik. Untuk specimen metalografi dilakukan proses penghalusan, pemolesan, etching dengan cairan Kellers Reagent ${ }^{[9]}$, dan pembersihan. Berikut adalah ilustrasi dimensi specimen yang digunakan dalam proses penelitian ini:

a. Specimen metalografi

Dalam pengujian metalografi, sample diambil dari bagian hasil cor seperti pada gambar 6 untuk kemudian dibentuk seperti pada Gambar 7.

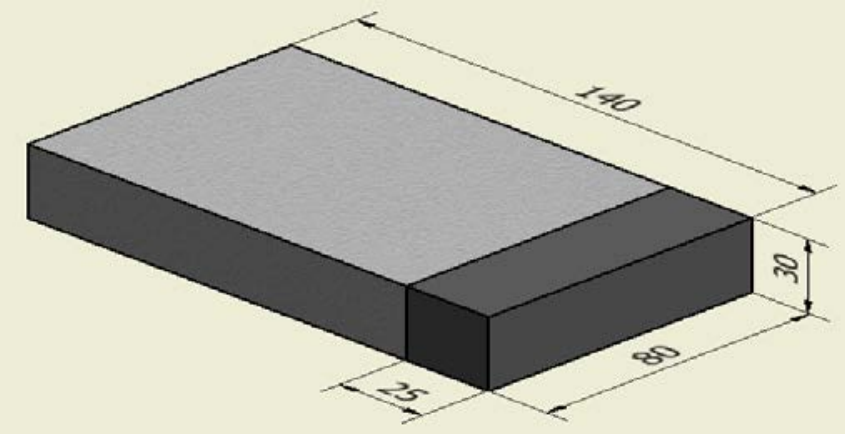

Gambar 6. Ilustrasi Posisi Sample yang Diambil Untuk Pengujian Metalografi (skala $1: 2$ )

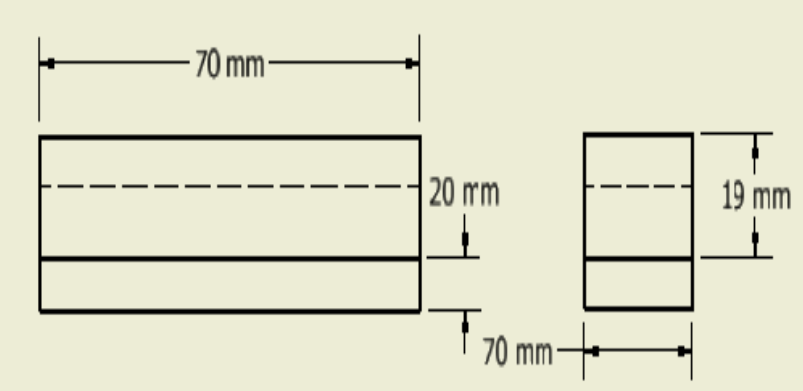

Gambar 7. Ilustrasi Dimensi Dari Specimen Metalografi (skala 1 : 2) 
b. Specimen pengujian tarik

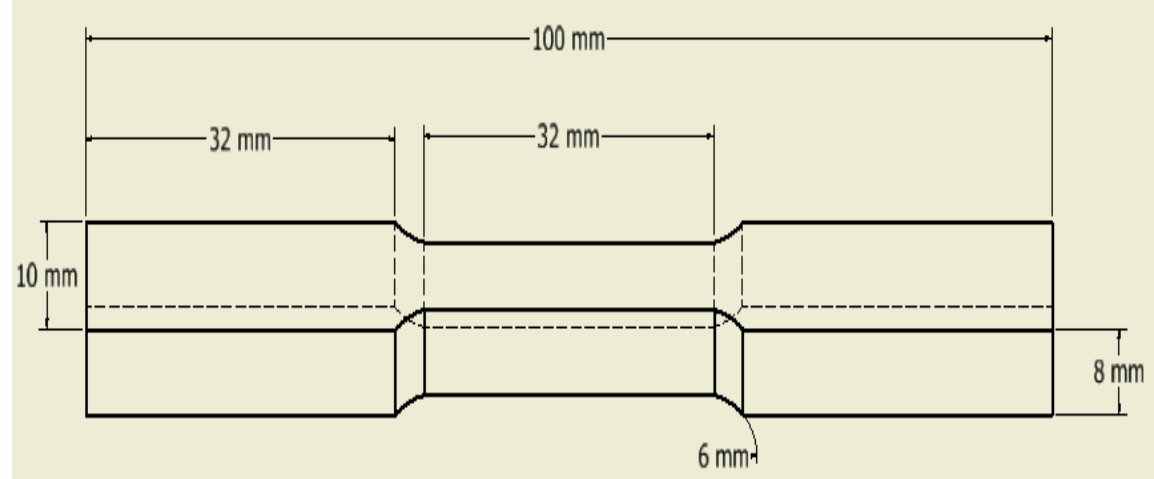

Gambar 8. Ilustrasi Dimensi Specimen Pengujian Tarik Berdasarkan ASTM a370-a12 (skala 1.5 : 1)

c. Specimen Pengujian Brinell

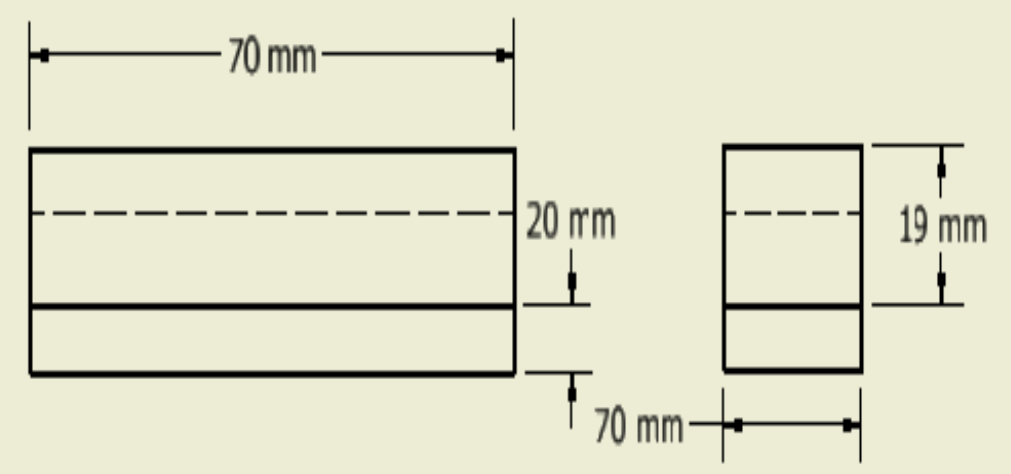

Gambar 7 Ilustrasi Dimensi Dari Specimen Metalografi (skala $1: 2$ )

\section{HASIL DAN PEMBAHASAN}

\section{Hasil Penelitian}

\section{Komposisi Bahan Baku Cor}

Tabel 1 Komposisi Bahan Baku Crank Case Hasil Spectrometer (\% Weight)

\begin{tabular}{cccccc}
\hline $\begin{array}{c}\mathrm{Si} \\
(\%)\end{array}$ & $\begin{array}{c}\mathrm{Fe} \\
(\%)\end{array}$ & $\begin{array}{c}\mathrm{Cu} \\
(\%)\end{array}$ & $\begin{array}{c}\mathrm{Mn} \\
(\%)\end{array}$ & $\begin{array}{c}\text { Mg } \\
(\%)\end{array}$ & $\begin{array}{c}\mathrm{Zn} \\
(\%)\end{array}$ \\
\hline 6.51 & 0,880 & 2.55 & 0.272 & 0.346 & 0.563 \\
\hline $\mathrm{Cr}$ & $\mathrm{Ni}$ & $\mathrm{Ti}$ & $\mathrm{Pb}$ & $\mathrm{Sn}$ & $\mathrm{Al}$ \\
$(\%)$ & $(\%)$ & $(\%)$ & $(\%)$ & $(\%)$ & $(\%)$ \\
\hline 0,017 & 0.254 & 0.024 & 0.177 & 0.101 & Bal \\
\hline (sumber: lab Departemen Teknik Metalurgi \& Material, Universitas Indonesia) \\
\multicolumn{7}{c}{} \\
\hline Tabel 2 Mechanical Properties Aluminium Alloy 319 \\
\hline 131 MPa & Tensile Strength & Elongation & Brinell Hardness \\
\hline
\end{tabular}




\section{Hasil Fisik Bahan Cor}

Berdasarkan tahapan proses pengecoran yang dilakukan seperti pada gambar 4 didapat hasil cor seperti pada Gambar 8.

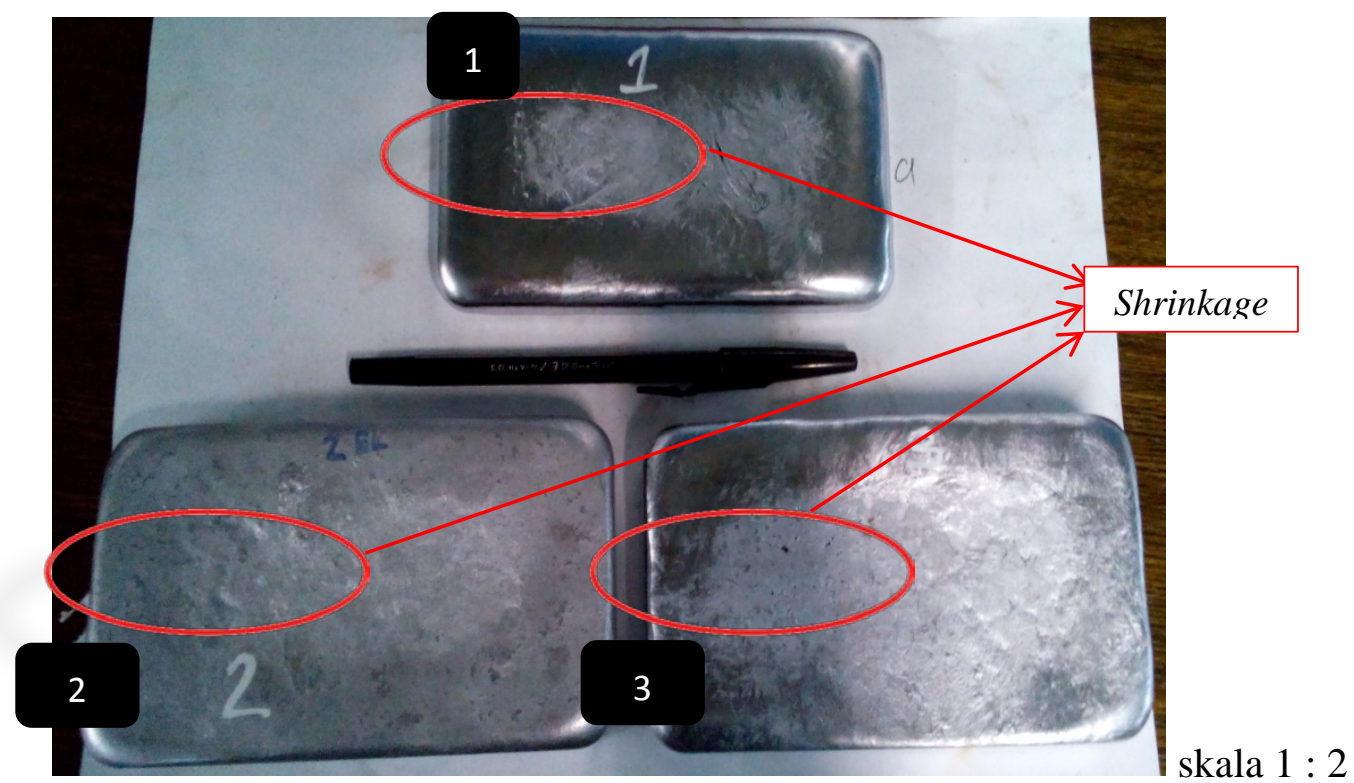

Gambar 8. Hasil Fisik Bahan Cor Dengan Menggunakan 1 = udara terbuka; 2 = bantuan media pasir basah; 3 = bantuan media pasir kering

Terlihat dari Gambar 8 bahwa shrinkage yang terjadi pada hasil cor berjenis pipe. Berdasarkan urutan shrinkage, media yang menggunakan bantuan media pasir basah terlihat lebih baik dibandingkan dengan udara terbuka dan pasir kering. Dalam hasil cor ini juga terlihat adanya sedikit porositas pada proses pembekuan dengan bantuan media pasir kering, namun pada proses pendinginan dengan bantuan media pasir basah dan udara terbuka tidak terlihat adanya porositas.

Shrinkage terjadi kerena laju proses pembekuan antara bagian tepi dengan bagian tengah hasil cor tidak sama akibat perbedaan penyerapan panas dari cetakan. Selain itu, terjadinya shrinkage bisa dicegah dengan melakukan proses pembekuan terarah, yaitu dengan menyamakan laju proses pembekuan pada bagian tepi hasil cor dengan bagian tengah.

\section{Hasil Pendataan Laju Penurunan Temperatur Pada Proses Pembekuan}

Pada Tabel 3 dapat dilihat laju waktu proses pembekuan hasil cor hingga mencapai suhu normal yaitu $31^{0} \mathrm{C}$.

Tabel 3. Laju Waktu Proses Pembekuan Hasil Cor

\begin{tabular}{cccc}
\hline Waktu ( Menit ) & Udara terbuka $\left({ }^{0} \mathrm{c}\right)$ & Pasir kering $\left({ }^{0} \mathrm{c}\right)$ & Pasir basah $\left({ }^{0} \mathrm{c}\right)$ \\
\hline 0 & 430 & 425 & 420 \\
10 & 240 & 247 & 220 \\
20 & 184 & 191 & 161 \\
30 & 151 & 169 & 121 \\
40 & 121 & 147 & 95 \\
50 & 103 & 121 & 72 \\
60 & 79 & 109 & 59 \\
70 & 56 & 87 & 47 \\
80 & 45 & 69 & 38 \\
90 & 39 & 54 & 34 \\
100 & 37 & 45 & 33 \\
110 & 34 & 41 & 32 \\
120 & 34 & 38 & 31 \\
\hline
\end{tabular}


Lanjutan Tabel 3. Laju Waktu Proses Pembekuan Hasil Cor

\begin{tabular}{cccc}
\hline Waktu ( Menit ) & Udara terbuka $\left({ }^{0} \mathrm{c}\right)$ & Pasir kering $\left({ }^{0} \mathrm{c}\right)$ & Pasir basah $\left({ }^{0} \mathrm{c}\right)$ \\
\hline 130 & 33 & 37 \\
140 & 32 & 35 \\
150 & 31 & 35 \\
160 & & 34 \\
170 & & 34 \\
180 & & 33 \\
190 & & 31 \\
\hline
\end{tabular}

Dari Tabel 3, terlihat laju waktu proses pembekuan pada cetakan logam menggunakan bantuan media pasir basah lebih cepat mencapai suhu normal yaitu 120 menit dibandingankan dengan media suhu udara terbuka 150 menit dan bantuan media pasir kering 190 menit. Grafik laju waktu proses pembekuan bahan cor dapat dilihat pada gambar 9.

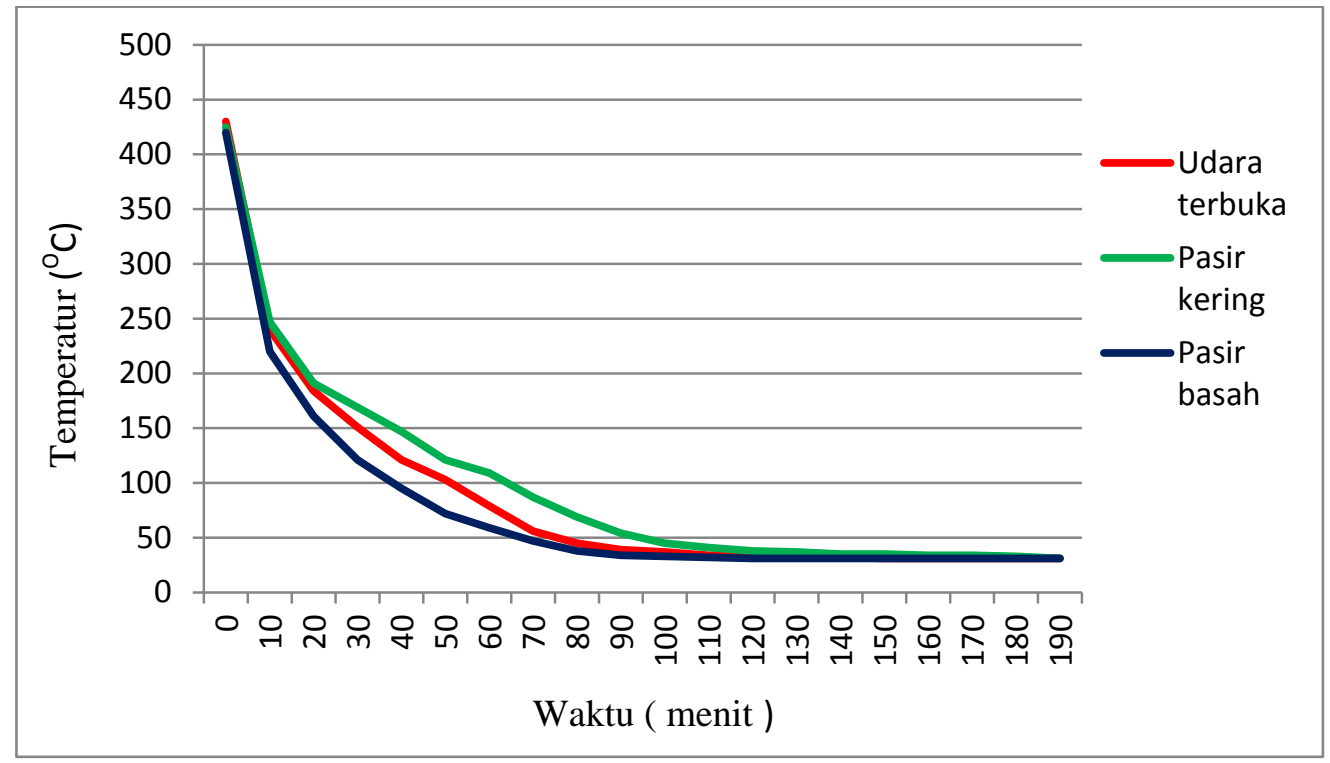

Gambar 9. Grafik Laju Waktu Proses Pembekuan Bahan Cor

\section{Hasil Pengujian Metalografi}

Gambar 10 sampai 12 merupakan hasil pengujian metalografi dengan menggunakan mikroskop tipe Jenco BC 4-311 pada cetakan logam dengan perbedaan laju proses pembekuan.

a. Udara terbuka

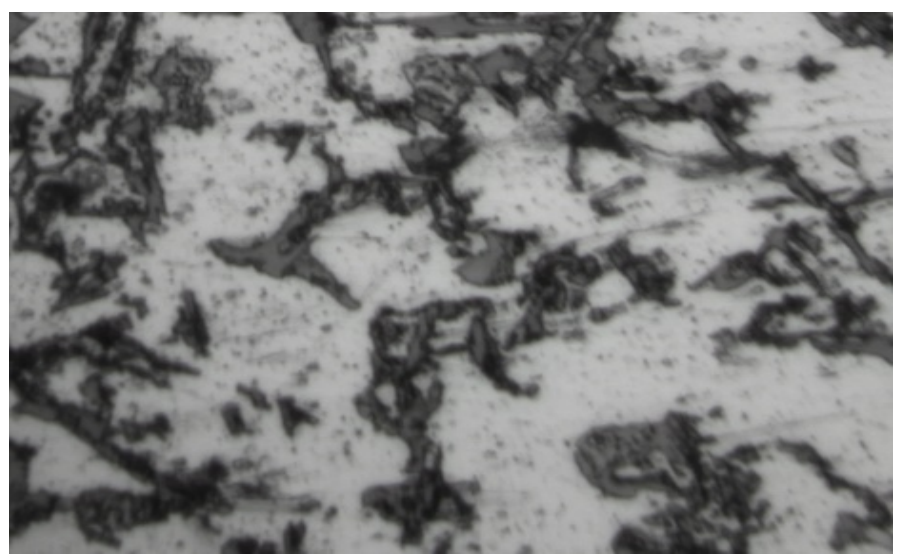

Gambar 10. Memperlihatkan gambar struktur mikro hasil penurunan laju proses pembekuan dengan media udara terbuka menggunakan etsa $0,5 \%$ Kellers Reagent dengan perbesaran 500x 
b. Bantuan media pasir basah

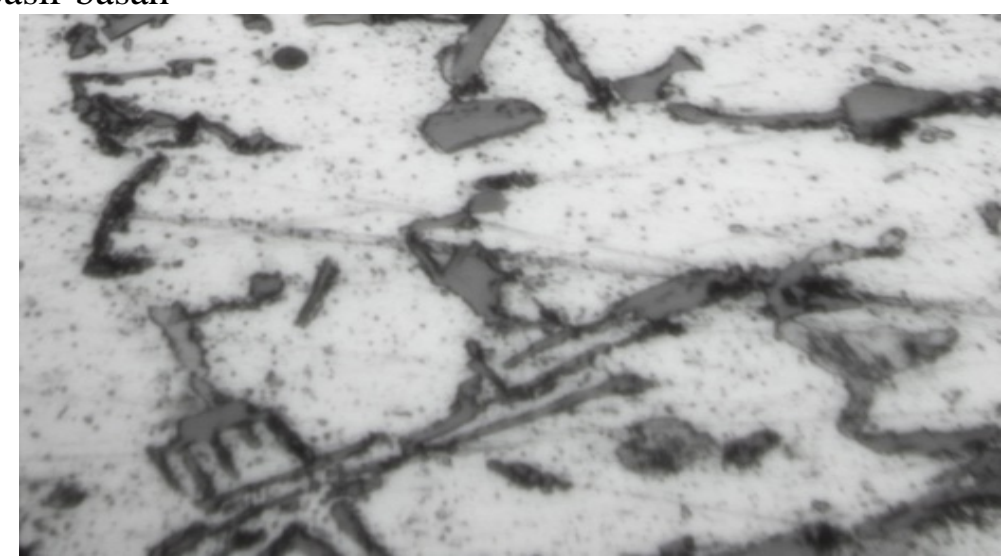

Gambar 11. Memperlihatkan gambar struktur mikro hasil penurunan laju proses pembekuan dengan media pasir kering menggunakan etsa Kellers Reagent dengan perbesaran 500x

c. Bantuan media pasir basah

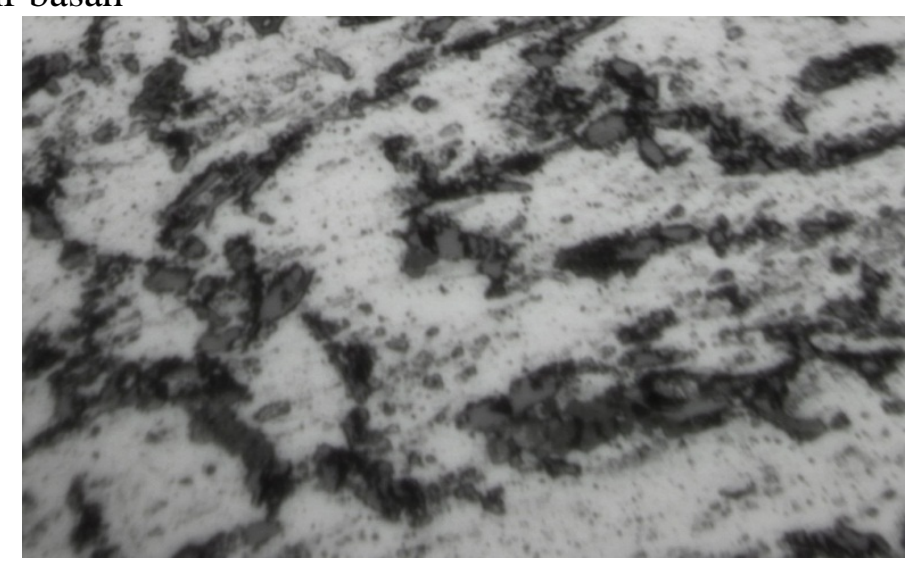

Gambar 12. Memperlihatkan gambar struktur mikro hasil penurunan laju proses pembekuan media pasir basah menggunakan etsa Kellers Reagent dengan perbesaran 500x

\section{Hasil Pengujian Tarik}

Pada Tabel 4 dapat dilihat hasil pengujian tarik pada hasil cor yang dilakukan di lab Metalurgi Fisik, Universitas Tarumanagara.

Tabel 4. Hasil Rata-Rata Pengujian Tarik Bahan Cor Menggunakan Cetakan Logam

\begin{tabular}{|c|c|c|c|c|c|c|c|}
\hline \multirow[b]{2}{*}{ Variasi } & Gauge & Length & & & & & \\
\hline & $\begin{array}{l}\text { Lebar } \\
(\mathrm{cm})\end{array}$ & $\begin{array}{l}\text { Tebal } \\
(\mathrm{cm})\end{array}$ & $\begin{array}{c}\mathrm{A} \\
\left(\mathrm{cm}^{2}\right)\end{array}$ & $\begin{array}{c}\text { Yield } \\
\text { kgf ) }\end{array}$ & $\begin{array}{l}\text { UTS } \\
\text { ( kgf ) }\end{array}$ & 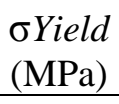 & $\begin{array}{l}\sigma U T S \\
(\mathrm{MPa})\end{array}$ \\
\hline $\begin{array}{l}\text { Udara } \\
\text { terbuka }\end{array}$ & 0,625 & 0,6 & 0,375 & 821,67 & 856,67 & 214,87 & 224,03 \\
\hline $\begin{array}{l}\text { Pasir } \\
\text { kering }\end{array}$ & 0,625 & 0,6 & 0,375 & 703,33 & 730 & 183,92 & 190,9 \\
\hline $\begin{array}{l}\text { Pasir } \\
\text { basah }\end{array}$ & 0,625 & 0,6 & 0,375 & 883,33 & 925 & 230,9 & 241,89 \\
\hline
\end{tabular}

Dari Tabel 4 diperoleh proses pembekuan dengan media pasir basah memiliki nilai yield strength dan ultimate tensile strength paling besar yaitu 230,9 MPa dan 241,89 MPa dibandingkan dengan media udara terbuka dan media pasir yaitu 214,87 MPa dan 224,03 MPa untuk media udara terbuka, 230,9 MPa dan 241,89 MPa untuk media pasir kering. 


\section{Hasil Pengujian Kekerasan Metode Brinell}

Pada Tabel 5 dapat dilihat hasil pengujian tarik pada hasil cor yang dilakukan di lab Metalurgi Fisik, Universitas Tarumanagara.

Tabel 5. Hasil pengujian kekerasan Metode Brinell

\begin{tabular}{cccc}
\hline No & \multicolumn{3}{c}{ Kekerasan } \\
\cline { 2 - 4 } & $\begin{array}{c}\text { Udara terbuka } \\
(\text { BHN })\end{array}$ & $\begin{array}{c}\text { Pasir kering } \\
(\text { BHN })\end{array}$ & $\begin{array}{c}\text { Pasir Basah } \\
(\text { BHN })\end{array}$ \\
\hline 1 & 64 & 56 & 65 \\
2 & 60 & 54 & 68 \\
3 & 62 & 53 & 71 \\
\hline Rata-rata & 62 & 54 & 68 \\
\hline
\end{tabular}

Dari Tabel 5 diperoleh bahwa laju waktu proses pembekuan bahan cor menggunakan cetakan logam dengan media pasir basah memiliki nilai kekerasan paling besar yaitu 68 BHN dibandingkan dengan media udara terbuka sebesar 62 BHN dan media pasir kering 54 BHN.

\section{PEMBAHASAN PENELITIAN}

\section{Pembahasan Hasil Spectrometer Bahan Cor}

Pada pengujian komposisi kimia yang dapat dilihat pada Tabel 1 di lab Departemen Teknik Metalurgi \& Material, Universitas Indonesia memperlihatkan bahwa kandungan dari bahan baku cor (crank case) merupakan aluminium paduan silikon (Al-Si) dengan kandungan si sebesar 6,51\%. Gambar 13 merupakan diagram fasa dari Al-Si.

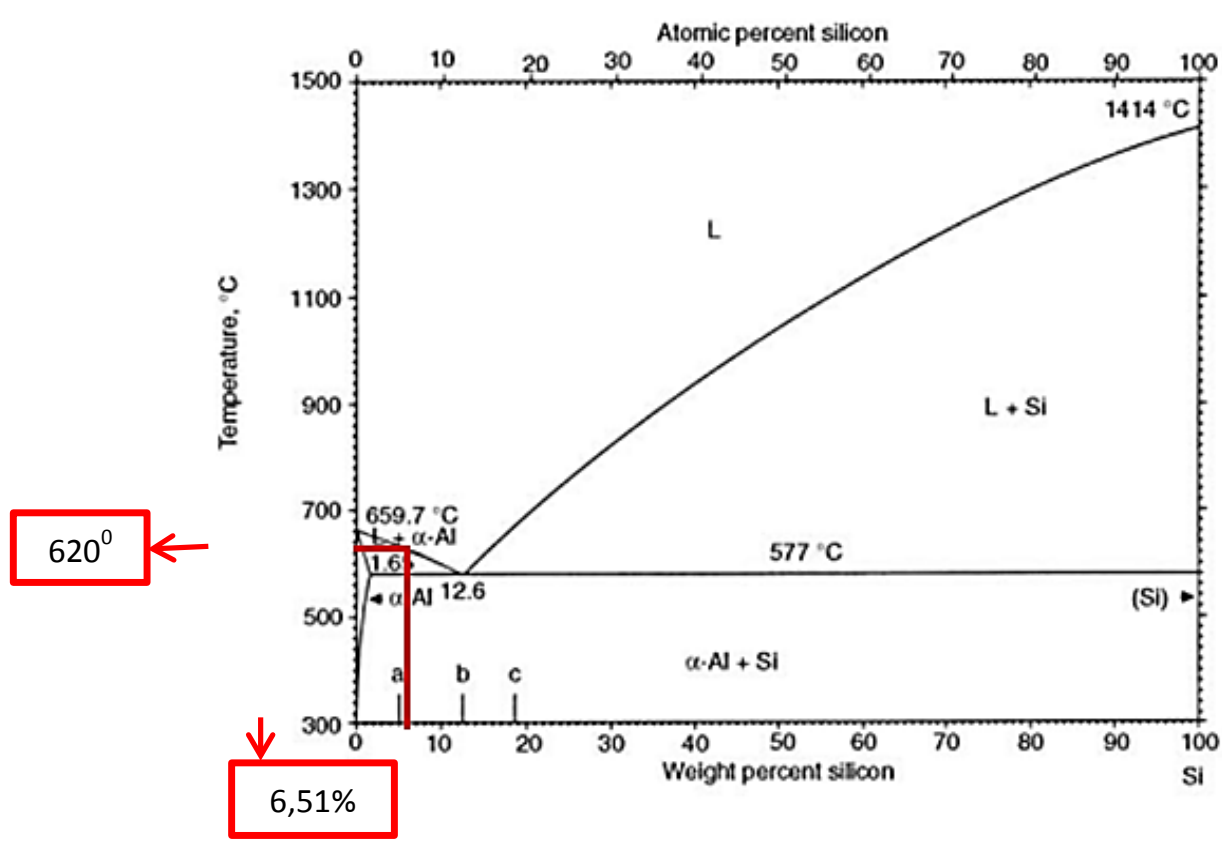

Gambar 13. Diagram Fasa Al-Si

Berdasarkan gambar 13 diperoleh titik lebur dari kandungan silikon 6,51\% sebesar $620^{\circ} \mathrm{C}$, sehingga pada proses peleburan dapat ditentukan batas temperatur yang sesuai pada saat proses penuangan. Pada penelitian ini, material bahan cor dipanaskan hingga $720^{\circ} \mathrm{C}$, hal ini dimaksudkan agar pada saat proses pengeluran crucible hingga proses penuangan ke cetakan logam temperatur dari bahan baku cor tetap pada temperatur yang tepat.

Dari diagram fasa Al-Si dengan kandungan Si sebesar 6,51\% terdapat 3 fasa yang terjadi yaitu fasa solid yang berada pada suhu $<577^{\circ} \mathrm{C}$, fasa lumpur $577^{\circ} \mathrm{C} \mathrm{s} / \mathrm{d} 620^{\circ} \mathrm{C}$, dan fasa cair $>620^{\circ} \mathrm{C}$. 


\section{Pembahasan Fisik Bahan Cor}

\section{a. Shrinkage}

Shrinkage merupakan penyusutan yang terjadi akibat laju pembekuan didalam cetakan tidak sama antara bagian tengah dengan bagian pinggir cetakan ${ }^{[8]}$. Proses pembekuan pada pinggir cetakan akan terjadi lebih cepat dibandingkan dengan bagian tengah cetakan, perubahan fasa dari cair menjadi solid akan melewati fasa lumpur terlebih dahulu hal ini yang menyebabkan terjadinya shrinkage.

\section{b. Porositas}

Porositas merupakan salah satu jenis cacat cor, hal ini terjadi karena terperangkapnya udara pada saat proses pembekuan dan terjadi seiring dengan terjadinya shrinkage. Porositas juga bisa disebabkan oleh gas hidrogen terperangkap pada saat proses pembekuan ${ }^{[8]}$. Pada penelitian ini porositas terlihat hanya pada proses pendinginan dengan media pasir kering. Hal ini dikarenakan proses pembekuan pada udara terbuka dan media pasir basah hanya terdapat sedikit shringkage. Gambar 14 sampai 16 merupakan foto dari permukaan hasil cor.

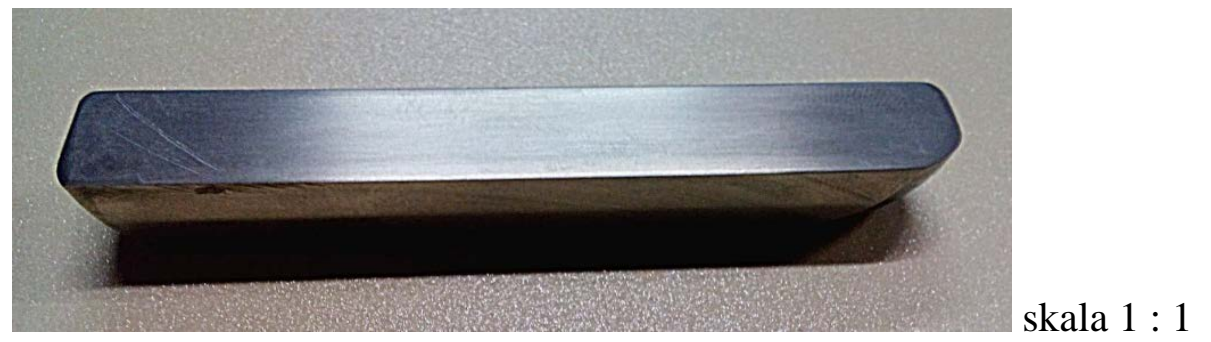

Gambar 14 Hasil Fisik Permukaan Benda Cor Pada Pendinginan Dengan Udara Terbuka

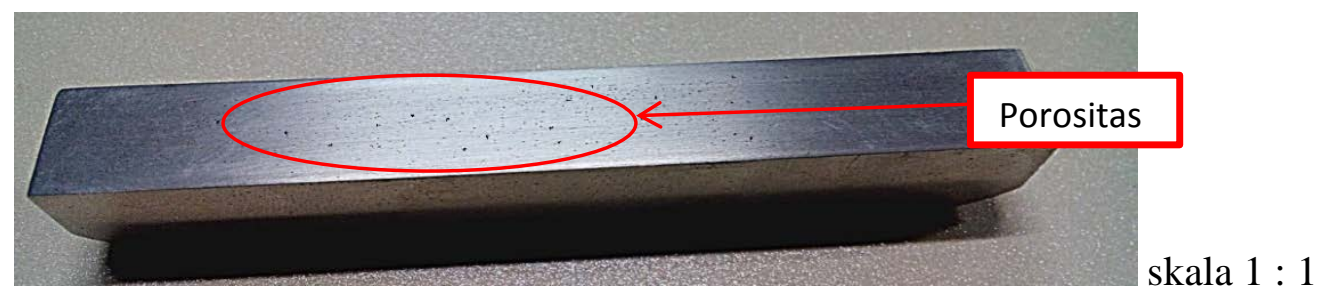

Gambar 15 Hasil Fisik Permukaan Benda Cor Pada Pendinginan Dengan Media Pasir Kering

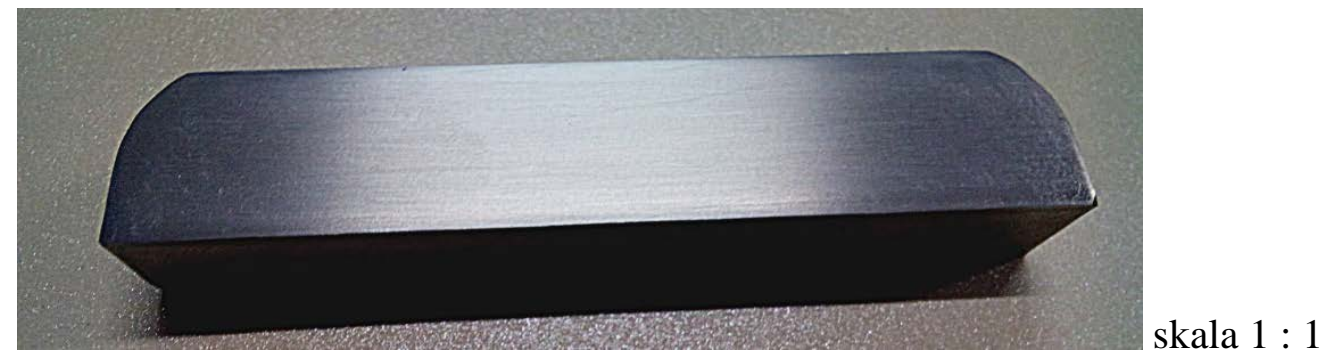

Gambar 16 Hasil Fisik Permukaan Benda Cor Pada Pendinginan Dengan Media Pasir Basah

\section{Pembahasan Metalografi Bahan Cor}

Berdasarkan pengamatan struktur mikro yang telah dilakukan, terdapat perbedaan antara struktur mikro hasil cor dengan media udara terbuka, media pasir kering, dan media pasir basah seperti gambar 4.2 sampai 4.4 maka diperoleh kesimpulan semakin cepat proses pembekuan maka struktur dendrit yang dihasilkan semakin kecil dan persebaran butirnya lebih merata, semakin lama proses pembekuan maka struktur dendrit yang dihasilkan semakin besar dan persebaran butirnya menjadi tidak merata. Hal ini senada dengan peryataan Dobrzański bahwa besar butir berbanding 
lurus dengan laju pembekuan, semakin cepat proses pembekuan besar butir yang dihasilkan semakin kecil dan persebaran butirnya menjadi lebih merata.

\section{Pembahasan Pengujian Tarik Bahan Cor}

Berdasarkan hasil pengujian tarik yang terlihat pada Tabel 4 maka dapat dibuat hubungan antara kekuatan tarik dengan variasi laju waktu proses pembekuan seperti pada Gambar 17 sampai 19.

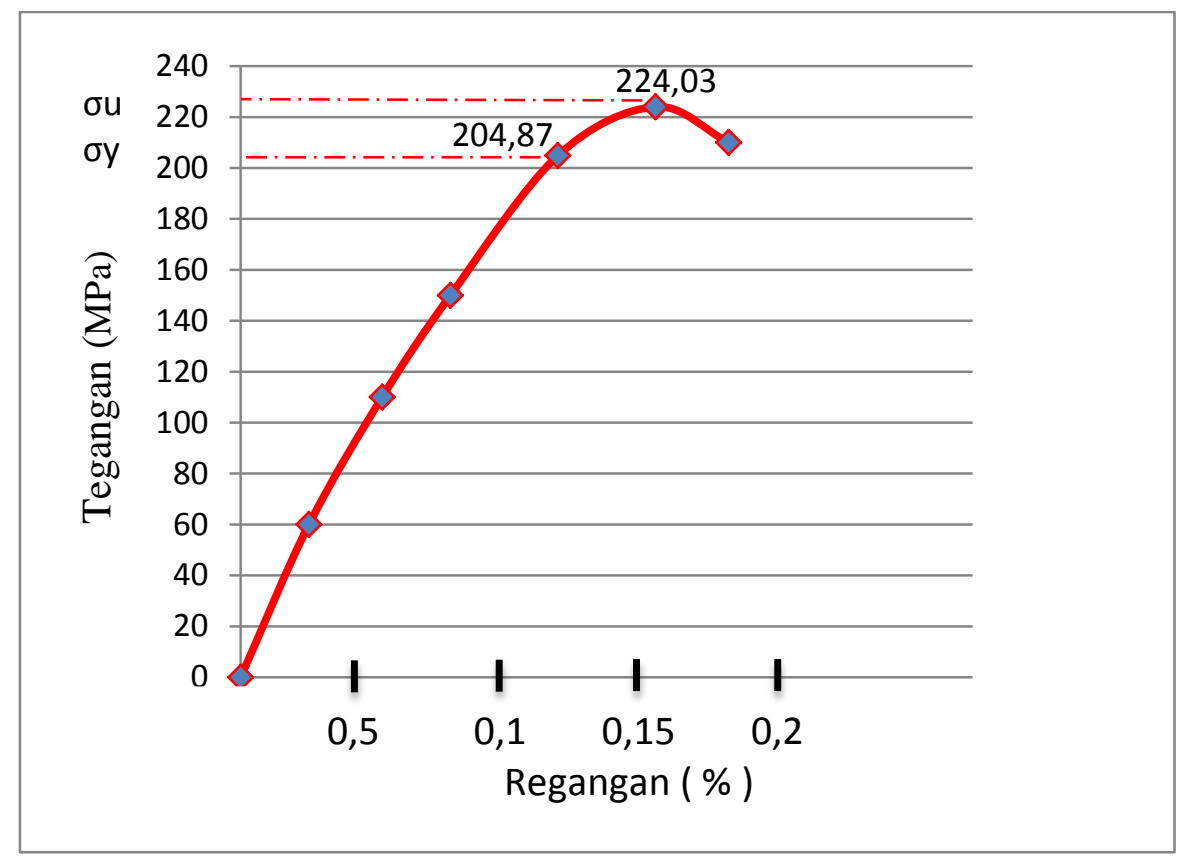

Gambar 17. Grafik Tegangan-Regangan Hasil Pengujian Tarik Dengan Media Udara Terbuka

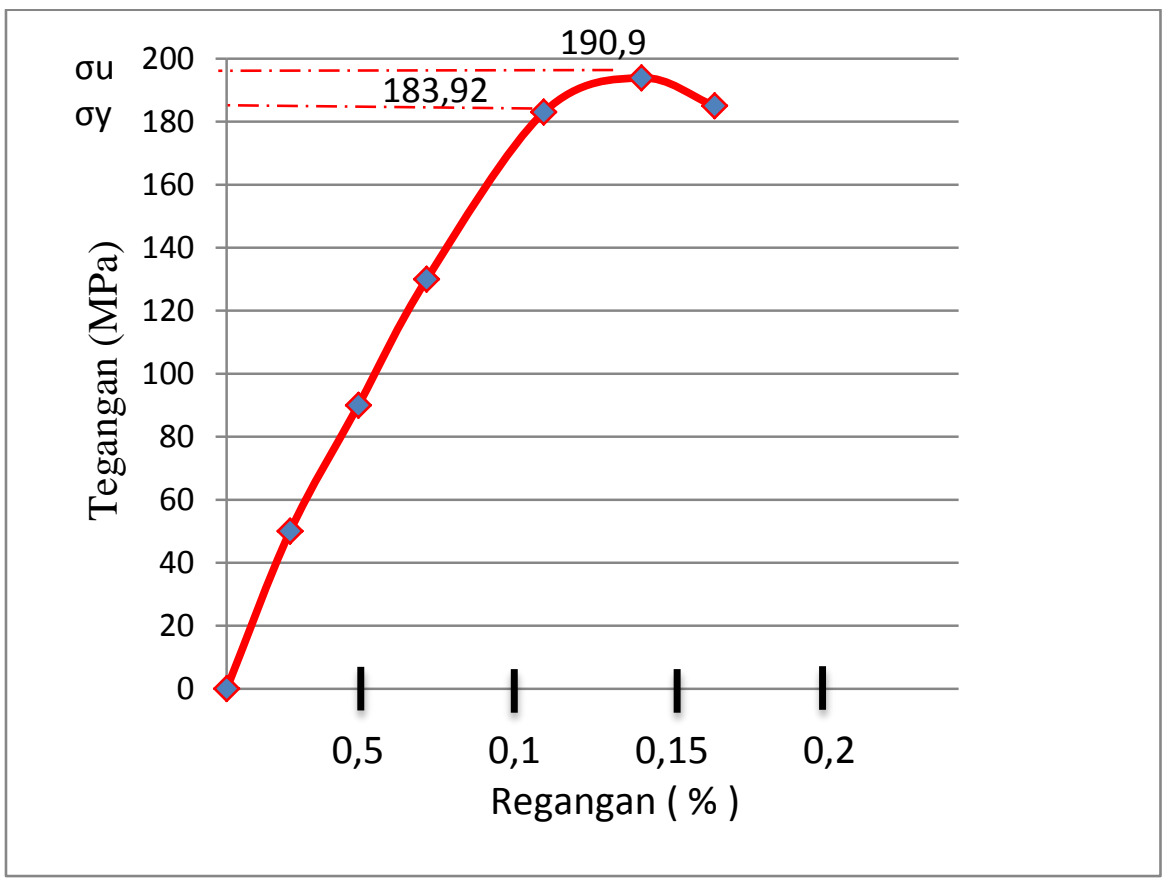

Gambar 18. Grafik Tegangan-Regangan Hasil Pengujian Tarik Dengan Media Pasir Kering 


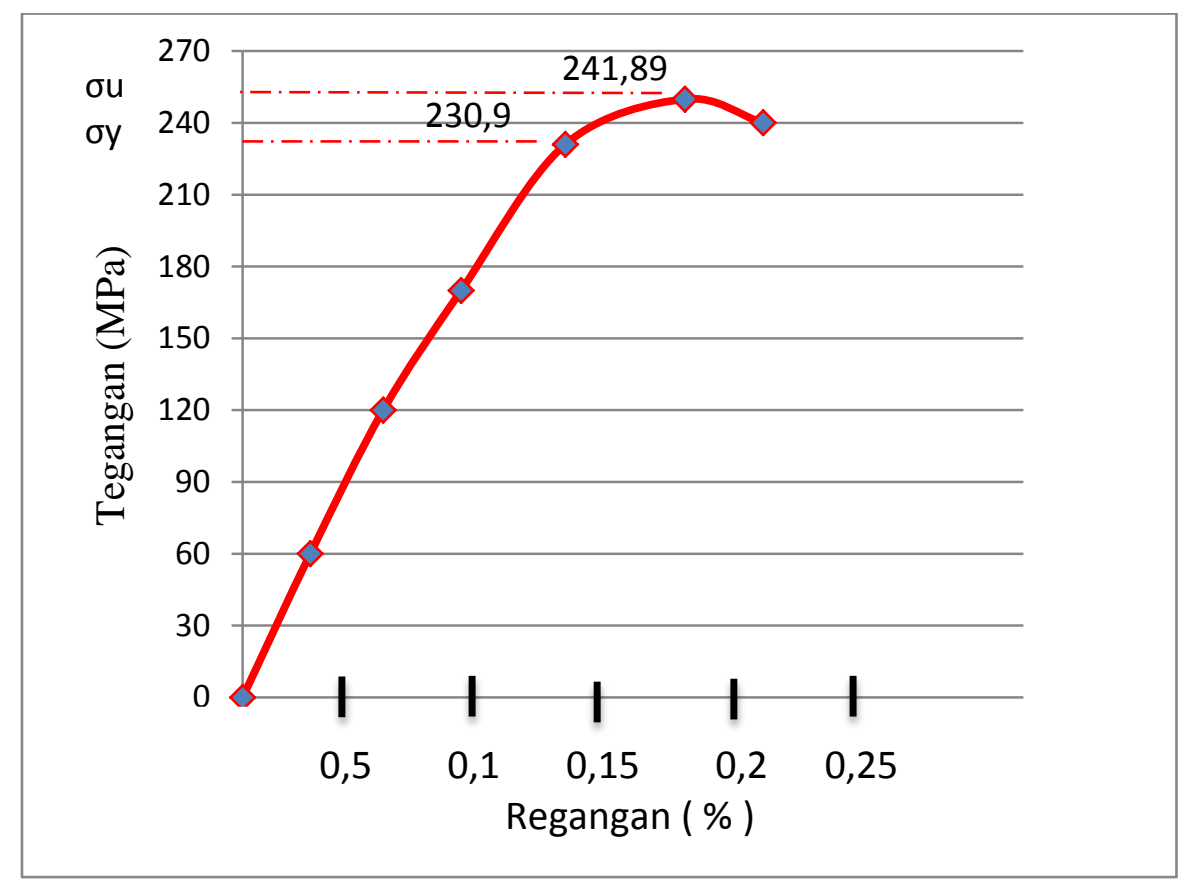

Gambar 19. Grafik Tegangan-Regangan Hasil Pengujian Tarik Dengan Media Pasir Basah

Berdasarkan Gambar 17 sampai 19, laju proses pendinginan dengan media pasir basah memiliki nilai yield dan ultimate tensile strength paling besar yaitu sebesar 214,87 MPa dan 224,03 MPa dibandingkan dengan udara terbuka dan media pasir kering, seperti pada Gambar 20. Hal ini dikarenakan hasil cor dengan media pasir basah memiliki persebaran butir yang merata dibandingkan dengan media udara terbuka dan media pasir seperti terlihat pada Gambar 10 sampai 12. Hal ini senada dengan peryataan Dobrzański bahwa butir yang lebih lembut serta lebih merata persebarannya berpengaruh terhadap peningkatan nilai kekuatan mekanik material.

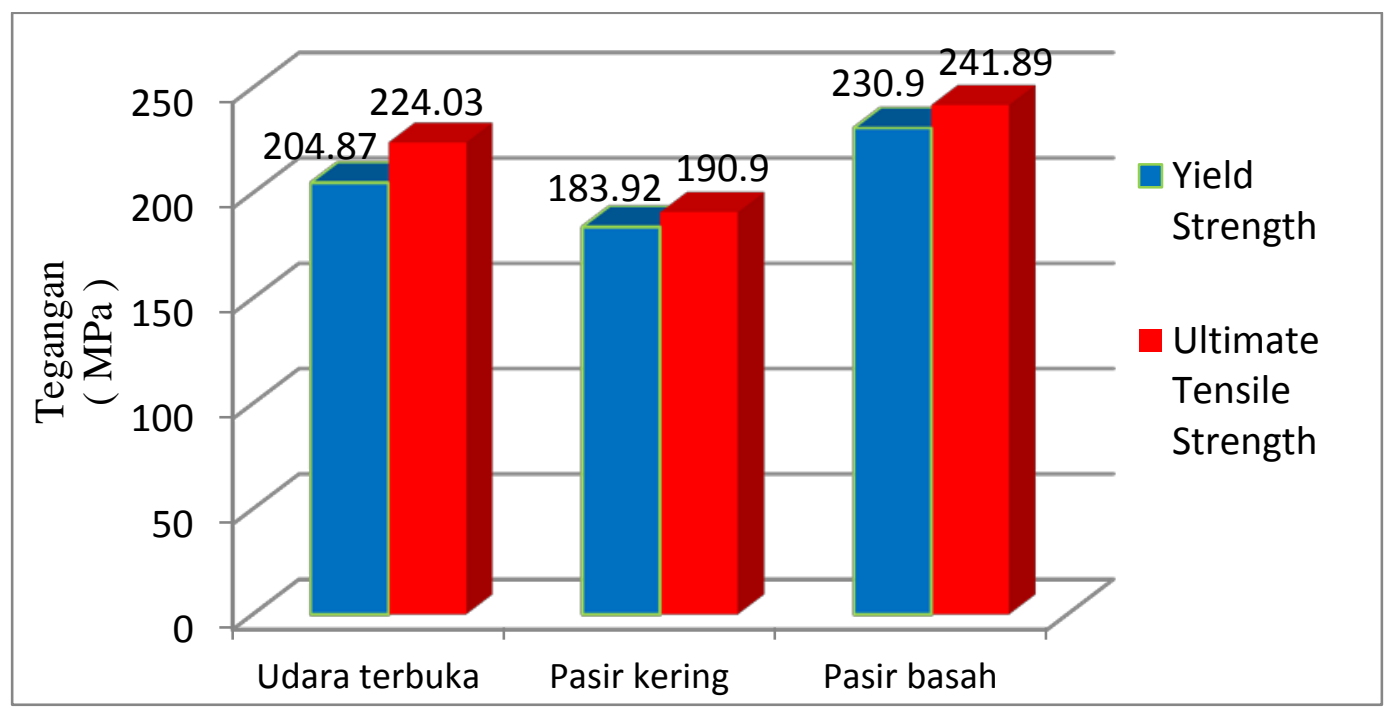

Gambar 20 Diagram Balok Hasil Uji Tarik Bahan Cor

\section{Pembahasan Pengujian kekerasan Brinell Bahan Cor}

Berdasarkan hasil penelitian pengujian kekerasan metode Brinell yang terlihat pada Tabel 5 maka dapat dibuat hubungan antara kekuatan tarik dengan variasi waktu proses pembekuan seperti pada Gambar 21. 


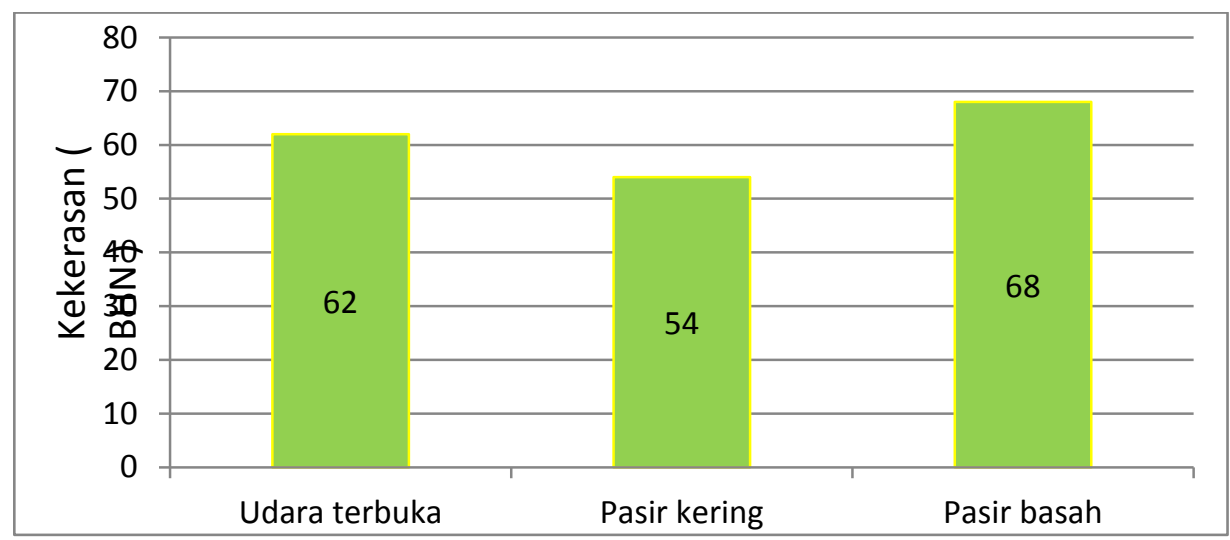

Gambar 21. Diagram Balok Hasil Pengujian Kekerasan Metode Brinell Bahan Cor

Berdasarkan Gambar 21 maka diperoleh proses pendinginan dengan media pasir basah memiliki nilai kekerasan paling tinggi sebesar 68 BHN dibandingkan dengan proses pembekuan dengan media udara terbuka yaitu 62 BHN dan media pasir kering yaitu 54 BHN. Seperti dengan pengujian tarik, sifat mekanik juga dipengaruhi oleh ukuran butir dan persebaran butirnya.

\section{Korelasi Hubungan Antara Nilai Kekuatan Tarik Dengan Nilai Kekerasan Bahan Cor}

Berdasarkan Tabel 4 dan Tabel 5 maka dapat dibuat grafik hubungan antara nilai kekuatan tarik dengan nilai kekerasan bahan baku cor (crank case) seperti Gambar 22 dan 23.

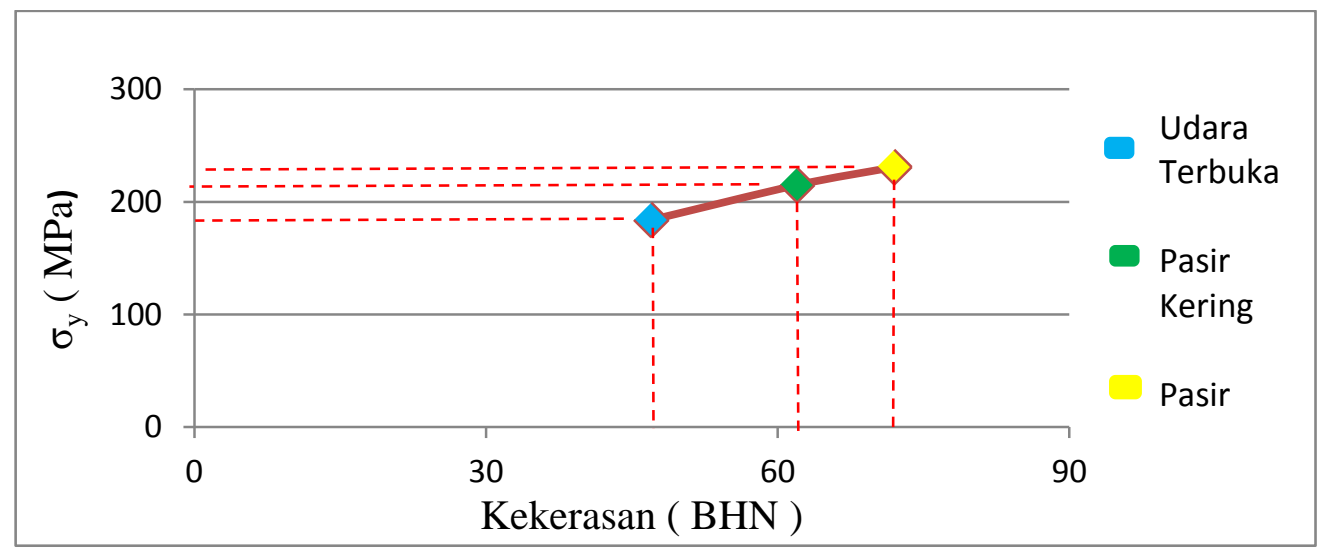

Gambar 22. Korelasi Antara Nilai Yield Strength Terhadap Nilai Kekerasan Bahan Cor

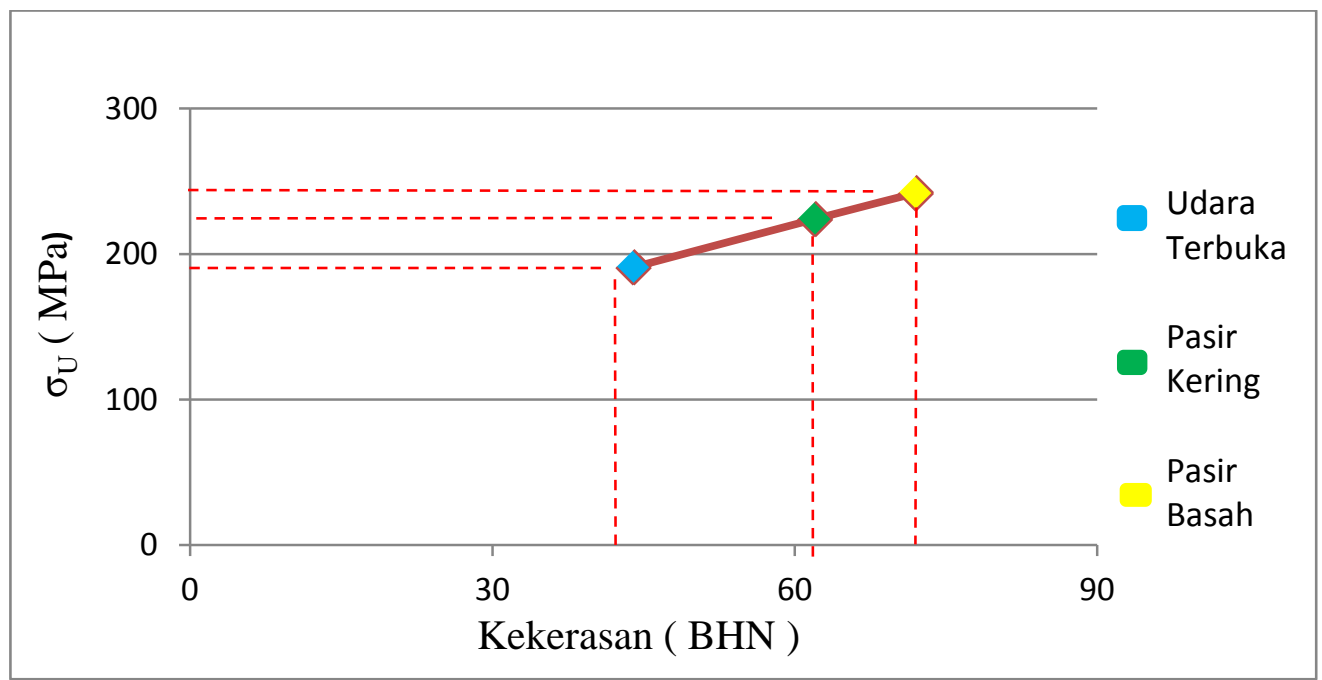

Gambar 23. Korelasi Antara Nilai UTS Terhadap Nilai Kekerasan Bahan Cor 
Berdasarkan gambar 22 dan 23 diperoleh kesimpulan bahwa besaran nilai tegangan bahan baku cor berbading lurus dengan nilai kekerasan. Semakin tinggi nilai tegangan, maka nilai kekerasan juga akan semakin meningkat.

\section{KESIMPULAN}

1. Berdasarkan nilai pengujian kekerasan Brinell, media perlambatan laju proses pembekuan yang menggunakan media pasir basah memiliki nilai kekuatan Brinell yaitu 68 BHN, media udara terbuka yaitu $62 \mathrm{BHN}$, dan media pasir kering yaitu $54 \mathrm{BHN}$.

2. Berdasarkan nilai pengujian tarik, perlambatan laju proses pembekuan yang menggunakan cetakan logam dengan media pasir basah diperoleh nilai yield strength 230,9 MPa dan ultimate tensile strength 241,89 MPa ; menggunakan cetakan logam dengan media udara terbuka diperoleh nilai yield strength 214,87 MPa dan ultimate tensile strength 224,03 MPa ; dan menggunakan cetakan logam dengan media pasir kering diperoleh nilai yield strength 183,92 MPa dan ultimate tensile strength 190,9 MPa.

3. Meningkatnya kekerasan pada logam aluminium alloy 319 berkaitan dengan besar butir yang dihasilkan oleh variasi waktu laju proses pembekuan. Semakin kecil besar butir yang dihasilkan dan persebarannya yang lebih merata, maka nilai kekuatan mekanis yang dihasilkan semakin besar.

\section{DAFTAR PUSTAKA}

[1] American Society for Testing and Material, ASTM STP, Vol 465, Philadelphia, PA, 1969.

[2] ASM Metal Handbook 8th Vol 7, Atlas Microstructure Of Industrial Alloys: American Society For Metal. 1998.

[3] Dobrzanski, L. A., Maniara R., J.H. Sokolowski, The Effect of Cooling Rate on Microeturcture and Mechanical Properties of AC AlSi9Cu Alloy. Poland:Silesian University of Technology, 2007.

[4] Surdia, Tata. Teknik Pengecoran Logam, vol 8, Jakarta : PT. Pradnya Paramita, 1996.

[5] Parker, Earl R. Materials Data Book. Barkeley. United States: University of California, 1967.

[6] F. A. Lewis, “ Alumunium Alloy Casting And Foundry “, Jhon Winley and Sons, New York, 1976. 